\title{
Interactions between Foreign Investment Treaties and Customary International Law
}

\author{
Maziyar Shokrani \\ Vice President and Researcher, \\ Law Justice and International Peace Institute (Lawjip) Esfahan, Iran
}

\begin{abstract}
The increasing number of investment treaties raises the issue of relationship between these treaties and public international law. This paper investigated and argued that the substantive norms introduced in these treaties can contribute greatly to sources of public international law through State practice and opinio juris from one hand and customary international law can be applied to international investment disputes on the other hand.
\end{abstract}

Keywords: FIT, CIL, Investment Law, International Law.

\section{THE CONCEPT OF INTERNATIONAL INVESTMENT LAW}

Developing friendly relations among nations is one of the obligations set forth by the Charter of the United Nations ${ }^{1}$. International investment, in my idea, is the most important phenomenon of our age which brings the peoples of the world together and makes them one family. This complex family is like a garden with flowers of one essence, although different in color, size, smell and characters. Therefore, this garden needs a law to make it more and more harmonious and productive. The international investment treaties emerged in 1950s for the purpose of regulating international investment affairs ${ }^{2}$ although its origins can be found in the expansion of European trade and investment activities from the seventeenth to early twenties centuries. ${ }^{3}$ Obviously, investment affairs are different, in nature, with other trading transactions whereas to invest in a foreign country "initiates a long-term relationship between the investor and the host country". ${ }^{4}$ International investment treaties are mainly composed of bilateral investment treaties (BITs) which rose in number drastically up to 2926 in $2015 .^{5}$ Today, the BITs, the Free Trade Agreements (FITs), along with other specialized multilateral agreements, constitutes today's international investment law regime. ${ }^{6}$ Such a large number of treaties is unprecedented in other areas of international law; notwithstanding under the rules of customary international law "no state is under an obligation to admit foreign investment in its territory, generally or in any particular segment of its economy". ${ }^{7}$ These facts show the emergence and necessity of developing international law in general, and, international

\footnotetext{
${ }^{1}$ Charter of the United Nations, Art. 1(2).

${ }^{2} \mathrm{CAI}$, Congyan, 'International Investment Treaties and the Formation, Application and Transformation of Customary International Law Rules', 7 Chinese J. Int'l L. 6592008.

3 Miles, Kate, The Origins of International Investment Law: Empire, Environment and the Safeguarding of Capital, Cambridge University Press (2013), p. 19.

4 Dolzer, Rudlof and Schreuer, Christoph, Principles of International Investment Law, Oxford University Press", Oxford/New York (2008), p. 3.

5 UNCTAD, World Investment Report (2015), p. 106. The number of BITs which was 500 in 1990, passed the 2500 mark in 2006. See supra note 4, p. 1.

${ }^{6}$ Sauvant, Karl P and Alvarez, Jose E, 'International Investment Law in Transition', in Sauvant, Karl P and Alvarez, Jose E (eds), The Evolving International Investment Regime: Expectations, Realities, Options, Oxford University Press (2011), xxxi-xxLi.

7 Id. 4 at 7.
} 
investment law in particular. The international investment law not only witnessed a huge number of treaties and agreements, but also a great number of cases brought to the international tribunals were involved in protection of foreign investment. ${ }^{8}$ The answer to the question that why investors need protection can be found in the business nature of a foreign investment. Foreign investments engage in long-term risk. The investors bear many commercial risks ranging from changes in the market to the changes affecting the financial settings. These changes may be feasible since they affect the domestic investors as well. What make a foreign investment more risky are the political risks. These risks, ie the risks inherent in a "future intervention" of the host state are normally addressed in an applicable investment treaty. ${ }^{9}$ These treaties which are binding upon the parties, are considered as sources of international law deriving from sources mentioned in Article 38 of the ICJ Statute including 'international conventions, whether general or particular, establishing rules expressly recognized' by States. International investment treaties influence another important source of international law as they serve as a driving force on customary international law; mentioned in the Article 38 of the ICJ namely 'international custom, as evidence of a general practice accepted as law'. In the next Chapters, the interactions between the international investment treaties and customary international law will be elaborated.

\section{EFFECTS OF INTERNATIONAL INVESTMENT TREATIES ON CIL}

Generally speaking, the custom as amounting to law can be traced back to the preliterate societies ${ }^{10}$ and is considered as original source of international law. ${ }^{11}$ Article 38 (1)(b) of the ICJ implies two constituent elements element of custom: State practice and the opinion juris. The former is the practice (action or inaction) of States in relation to each other or to other recognized international actors while the latter which is the conformity, with the belief of being in conformity, of behavior of States or other international actors to and established practice amounting to a general custom. ${ }^{12}$ These two elements form material (objective) and psychological (subjective) requirements of the custom and according to the prevailing international legal theories, "general practice" refers to the repeated and similar State practice and such State practice includes both action and inaction. The period for formation of CIL is debatable and differs in different jurisdictions: According to the U.S. Supreme Court it may take several decades or even centuries; France takes the position that minimum thirty years is required while U.K. considers no less than forty years. ${ }^{13}$ Brownlie does not consider a particular duration of time as a requirement for recognizing custom as he said " $\mathrm{A}$ long (and, much less, an immemorial) practice is not necessary"14which, to some extent, supports the role of power in formation of CIL, as Sornarajah says "The role of power in this area is evident...Powerful states sought to construct rules of investment protection largely aimed at developing states by espousing them in their practice and passing them off as customary principles". ${ }^{15}$ Before going to the effect of international investment treaties, we must realize the relationship between the treaty law and CIL. Codification of CIL, in the easiest way, can be

\footnotetext{
${ }^{8}$ Iran-United States Claims Tribunal already finalized over 3900 cases, www.iusct.net, accessed on 07.11.2015, and, more than 550 cases have been administered by International Center for Settlement of Investment Disputes (ICSID) to date, www.icsid.worldbank.org, accessed on 06.12.2015.

${ }^{9}$ Id 4 at 4.

10 Thirlway, Hugh, The Sources of International Law, Oxford University Press (2014), pp. 63

11 Id 3.

12 Id. 11 at 63-73.

${ }^{13}$ Scharf, Michael P, Customary International Law in Times of Fundamental Change: Recognizing Grotian Moments, Cambridge University Press (2013), p. 7.

14 Brownlie, Ian, Principles of Public International Law, Oxford University Press (2008), p. 7.

15 Sornarajah, M., "The International Law on Foreign Investment”, Cambridge University Press (2010), p. 84.
} 
expressed as a purpose of a new multilateral treaty. ${ }^{16}$ These multilateral treaties are regarded as law-making treaties too. However, one of the sources that evidences of CIL are distilled, according to the United Nations International Law Commission, is inter-State diplomatic relations which forms treaty law and practice in general; ${ }^{17}$ therefore, dividing treaties to lawmaking and non-lawmaking (contractual) is not accepted by International Law Commission and by the Vienna Convention on the Law of Treaties (VCLT). ${ }^{18}$ The mentioned convention treats all of treaties equally. ${ }^{19}$ Thus, the treaties, either multilateral or bilateral, can create CIL rules if the elements of custom, as discussed, would be present and the investment treaties including bilateral treaties (BITs) are not exceptions as "no treaty can exist in isolation from general international law". ${ }^{20}$ At the same time, it must be reminded that "there is no presumption that a series of treaties gives rise to a new rule of customary law, though this does not preclude such a metamorphosis occurring in particular cases". ${ }^{21}$ Besides, the interpretation of the treaty may be obtained beyond the scope of the treaty. The terms of the treaty, in relation to general international law, may be interpreted in two ways which was approved in the first ICSID treaty arbitration ${ }^{22}$ :

(1) "Negatively that, in entering into treaty obligations, the parties intend not to act inconsistently with generally recognized principles of international law or with previous treaty obligations towards third States; and

(2) Positively that the parties are taken to 'refer to general principles of international law for all questions which [the treaty] does not itself resolve in express terms and in a different way'”.23

The negative approach, however, is challenged in practice. The North Atlantic Free Trade Agreement (NAFTA) requires that "Each Party shall accord investments of investors of another Party treatment in accordance with international law, including fair and equitable treatment..." ${ }^{24}$ which was settled by NAFTA Free Trade Commission by an interpretation of the Article that only 'prescribes the customary international law minimum standard of treatment of aliens, ${ }^{25}$ Still, according to some scholars, the relationship between CIL and investment treaties remains problematic, among the others, for the following reason: "It is evident that States have entered into investment treaties precisely in order to remedy perceived gaps or limitations in protections afforded by customary international law in the field of treatment of aliens...". ${ }^{26}$ Dumberry argues that BITs are missing the two necessary elements of custom:

\footnotetext{
16 Aust, Anthony, Handbook of International Law, Cambridge University Press, Cambridge (2005), p. 8.

17 Id. 3.

18 Vienna Convention on the Law of Treaties was adopted on 22 May 1969 and has been ratified by 114 States as of today.

${ }^{19}$ Although the VCLT treats bilateral and multilateral treaties equally, however, different rules may be applied to them as a result of the number of members. Art. 60(1) stipulates "A material breach of a bilateral treaty by one of the parties entitles the other to invoke the breach as a ground for terminating the treaty or suspending its operation in whole or in part." There are different arrangements for material breach of a multilateral treaty stipulated in the same Article.

${ }^{20}$ McLachlan QC, Campbell et al, International Investment Arbitration: Substantive Principles, Oxford University Press (2010), p. 15.

${ }^{21}$ Committee on Formation of Customary (General) International Law, London conference (2000), International Law Association, p. 759, Http://heinonline.org, accessed on 02.11.2015.

22 Asian Agricultural Products Ltd v Republic of Sri Lanka (Award) (ICSID, 1999, El-Kosheri P, Goldman \& Asante) 4 ICSID Rep 245, 265-266, Rule (D), in Id. 17.

${ }^{23}$ Id. 17 at 15.

24 Art. 1105.

25 NAFTA Free Trade Commission (FTC), Interpretation of NAFTA Chapter 11 (31 July 2001) 6 ICSID Rep 567, 568, in Id. 17 at 16.

26 Id. 17 at $17-18$
} 
There is no consistent State practice, and, BITs lack any opinion juris. ${ }^{27}$ As an evidence to his argument, Dumberry refers to Camuzzi International S.A. v. Argentina that "lex specialis cannot be considered as leading to a rule of customary law" which is supported by ICSID $^{28}$ which held that "there is no obstacle in international law to the expression of the will of States through treaties being at the same time an expression of practice and of the opinio juris necessary for the birth of a customary rule if the conditions for it are met." ${ }^{29}$ Concerning lack of opinion juris, Dumberry holds the position that "the requirement of the element of opinio juris has been repeatedly reiterated by arbitral tribunals deciding investor-State disputes... There is certainly no evidence of any opinio juris by States entering into BITs." ${ }^{30}$ Anderas Lowenfeld argued that He concludes that the substantive investment protections contained in BITs have moved "beyond lex specialis .. to the level of customary law effective even for non-signatories". ${ }^{31}$ As an Eastern scholar, Cai's position is more moderate: He believes that the role of international investment treaties in formation of CIL should neither be underestimated nor overestimated: "In this new changing context of international investment law, it is absolutely necessary for international society to examine the formation, application and transformation of CIL rules with an open mind. In this respect, international investment treaty practice, which is now mainly composed of by more than 2500 BITs, 240 FTAs and 290 investment arbitrations cases, can certainly become a forceful impetus to reshape the picture of CIL rules". ${ }^{32}$ Other scholars also see the CIL more accessible for the performance of attempts at facilitating compatibility between investment treaties and general international law. ${ }^{33}$

\section{APPLICATION OF CIL IN INVESTMENT DISPUTES (CASE STUDY)}

On application of CIL in foreign disputes, the dispute between Republic of Italy and Republic of Cuba are discussed in this Chapter. The dispute between Republic of Italy and Republic of Cuba $^{34}$ over the BIT which was signed on May 7, 199335, was brought to Ad Hoc Arbitral Tribunal in 2003. The Interim and Final Awards were delivered on March 15, 2005 and January 15, 2008 respectively. Drafting the BIT in Italian and delivering the Awards in French, made it so difficult for the Author to have direct access to these sources. The dispute originated in injuries that a group of several Italian companies, operating in a range of industry sectors, claimed to have suffered as a consequence of a series of acts attributable to Cuba. ${ }^{36}$ Invoking Article 10 of the BIT, Italy espoused these claims and, exercising diplomatic protection of these companies, which provides for ad hoc arbitration for the settlement of

\footnotetext{
27 Dumberry, Patrick, 'Are BITs Representing the New Customary International Law in International Investment Law?', 28 Penn St. Int'l L. Rev. 675 2009-2010, Http://heinonline.org, accessed on 02.11.2015.

${ }^{28}$ Camuzzi International S.A. v. Argentina, Dec. Jurisdiction 144 (May 11, 2005) (ICSID), in Id. 24.

29 Id.

30 Id. at 690.

31 E.g., Andreas F. Lowenfeld, Investment Agreements and International Law, 42 COLUM. J. TRANSNAT'L L. 123 (2003); Stephen M. Schwebel, The Influence of Bilateral Investment Treaties on Customary International Law, 98 Am. Soc'v INT'L L. 27 (2004), in Alvarez, Jose E., “A BIT on Custom”, 42 N.Y.U. J. Int'l L. \& Pol. 17 2009-2010, Http://heinonline.org, accessed on 02.11.2015.

32 Id. 3.

33 Lorz, Ralph Alexander, 'Fragmentation, Consolidation and the Future Relationship Between International Investment Law and General International Law,, in Baetens, Freya, (ed.), Investment Law within International Law: Integrationist Perspectives, Cambridge University Press (2013), pp. 482-493.

34 Republic of Italy v Republic of Cuba, Interim Award (2005), Ad Hoc Arbitral Tribunal, and, Republic of Italy v Republic of Cuba, Final Award (2008), Ad Hoc Arbitral Tribunal. www.italaw.com/cases.

35 Cuba-Italy BIT, www.italaw.com (in Italian) and http://www.unctad.org/sections/dite/iialdocs/bits/italycuba-it.pdf (in Italian).

36 Bederman, David J and Stewart, David P, (eds.), “International Decisions”, 106 Am. J. Int'l L. 3412012 , Http://heinonline.org, accessed on 06.12.2015.
} 
"disputes between the Contracting Parties concerning the interpretation and application" of the treaty ${ }^{37}$ as Cuba is not a member of the ICSID. Italy claimed that, Cuba had breached its obligations arising under the BIT; specifically, to encourage investments in its territory (Art. 2(1)); to grant the necessary authorizations to prospective investors; to provide fair and equitable treatment (Art. 2(2)); to abstain from arbitrary and discriminatory measures; to provide national treatment (Art. 3(2)); to provide full protection and security (Art. 5(1)); to refrain from expropriating investments (Art. 5(2)); and to guarantee the repatriation of invested capital (Art. 6), through the conduct either of its organs or of certain state-owned entities. ${ }^{38}$ The arbitration can be considered a landmark case to the since it has constituted the first inter-State proceedings in the history of modern BITs. ${ }^{39}$ The proceedings were highly relied on CIL rules as the cause of Italy's action was 'diplomatic protection' which is defined and regulated by customary rules. Besides, BIT did not contain any rule addressing the interplay between diplomatic protection and investment arbitration, as some other BITs do. ${ }^{40}$ The Tribunal rendered its final award, rejecting all of Italy's claims and Cuba's counter-claim; however, Both the preliminary judgment and the final award engage with the admissibility of Italy's claims in diplomatic protection and the application of the customary rule of exhaustion of local remedies ${ }^{41}$ which was objected by Cuba that Article lo of the BIT extended to disputes concerning the interpretation and application of the BIT only, and it would not cover the espousal of claims by either State for injuries caused to its own nationals. ${ }^{42}$ However, According to the Tribunal, the arbitration clause under Article 9 precludes an action in diplomatic protection, only if the investor institutes proceedings or gives its prior consent to arbitration ${ }^{43}$ and both Cuba's assertion that the mere presence of investor-State dispute settlement clauses in a BIT excludes reliance on diplomatic protection, and the argument that the State of nationality always enjoys the right to diplomatic protection, unless it has expressly waived it, have rejected. 44 "As a further preliminary objection, Cuba argued that, if Italy was truly acting in diplomatic protection, the Italian investors had not exhausted all local remedies available in the Cuban domestic legal system. Italy replied to Cuba's objection stating that it was acting primarily in its own right for the direct breach of the BIT" 45 In sum, Milano observes this case as confirming that customary international law remains central to the application and interpretation of BITs, when the claim has been brought at the inter-State level and that the harmonization between treaty and customary law is an important factor explaining the success of international investment law and arbitration among such diverse actors as private investors and States. ${ }^{46}$

\section{CONCLUSION}

The proliferation of international investment treaties and related case law emerged a new and significant area in international law and practice. The huge and unprecedented number of

\footnotetext{
37 Id.

38 Id.

39 Potests, Michele, 'Republic of Italy v. Republic of Cuba', American Journal of International Law (2012), 341, at 344 in Milano, Enrico, "The Investment Arbitration between Italy and Cuba: The Application of Customary International Law under Scrutiny", 11 Law \& Prac. Int'l Cts. \& Tribunals 499 2012, Http://heinonline.org, accessed on 02.11 .2015 .

40 Id. 37 at 345.

41 Milano, Enrico, 'The Investment Arbitration between Italy and Cuba: The Application of Customary International Law under Scrutiny', 11 Law \& Prac. Int'l Cts. \& Tribunals 499 2012, Http://heinonline.org, accessed on 02.11 .2015 .

42 Id.

43 Interim Award, Para. 65 in Id. 42.

44 Id. 42.

45 Id. At 509.

46 Id. At 524.
} 
treaties and cases in this area, rises interactions between foreign investment law and public international law in general, and customary international law in particular; although this may be resisted by developing countries as host-states. Apart from the extreme opponents and proponents that BITs could form CIL, the moderate idea that the role of international investment treaties in formation of CIL should neither be underestimated nor overestimated, seems more acceptable. On the other hand, the role of CIL in application and interpretation of BIT, as studied in Republic of Italy $v$ Republic of Cuba, cannot be denied as CIL remains central factor.

\section{References}

Alvarez, Jose E., 'A BIT on Custom', 42 N.Y.U. J. Int'l L. \& Pol. 17 2009-2010.

Alvarez, Jose E. and Sauvant, Karl P (eds), The Evolving International Investment Regime: Expectations, Realities, Options, Oxford University Press (2011).

Aust, Anthony, Handbook of International Law, Cambridge University Press, Cambridge (2005).

Baetens, Freya, (ed.) Investment Law within International Law: Integrationist Perspectives, Cambridge University Press (2013).

Bederman, David J and Stewart, David P, (eds.), 'International Decisions', 106 Am. J. Int'l L. 3412012.

Brownlie, Ian, Principles of Public International Law, Oxford University Press (2008), p. 7.

CAI, Congyan, 'International Investment Treaties and the Formation, Application and Transformation of Customary International Law Rules', 7 Chinese J. Int'l L. 6592008.

Dumberry, Patrick, 'Are BITs Representing the New Customary International Law in International Investment Law?', 28 Penn St. Int'l L. Rev. 675 2009-2010.

Dolzer, Rudlof and Schreuer, Christoph, Principles of International Investment Law", Oxford University Press, Oxford/New York (2008).

Lorz, Ralph Alexander, 'Fragmentation, Consolidation and the Future Relationship between International Investment Law and General International Law', in Baetens, Freya, (ed.) Investment Law within International Law: Integrationist Perspectives, Cambridge University Press (2013).

McLachlan QC, Campbell et al, International Investment Arbitration: Substantive Principles, Oxford University Press (2010).

Milano, Enrico, 'The Investment Arbitration between Italy and Cuba: The Application of Customary International Law under Scrutiny', 11 Law \& Prac. Int'l Cts. \& Tribunals 4992012.

Miles, Kate, The Origins of International Investment Law: Empire, Environment and the Safeguarding of Capital, Cambridge University Press (2013).

Potests, Michele, 'Republic of Italy v. Republic of Cuba', American Journal of International Law (2012).

Sauvant, Karl P and Alvarez, Jose E, 'International Investment Law in Transition', in Sauvant, Karl P and Alvarez, Jose E (eds.), The Evolving International Investment Regime: Expectations, Realities, Options, Oxford University Press (2011).

Scharf, Michael P, Customary International Law in Times of Fundamental Change: Recognizing Grotian Moments, Cambridge University Press (2013).

Sornarajah, M., The International Law on Foreign Investment, Cambridge University Press (2010).

Stephen M. Schwebel, 'The Influence of Bilateral Investment Treaties on Customary International Law', 98 Am. Soc'v INT'L L. 27 (2004).

Thirlway, Hugh, The Sources of International Law, Oxford University Press (2014).

\section{Table of Cases}

Asian Agricultural Products Ltd v Republic of Sri Lanka (ICSID)

Camuzzi International S.A. v Argentina (ICSID) 
Republic of Italy v Republic of Cuba, Interim Award (Ad Hoc Arbitral Tribunal)

Republic of Italy v Republic of Cuba, Final Award (Ad Hoc Arbitral Tribunal) 